\title{
PET imaging of infection with a HYNIC-conjugated LTB4 antagonist labeled with F-18 via hydrazone formation
}

\author{
Huub J.J.M. Rennen*, Peter Laverman, Julliëtte E.M. van Eerd, Wim J.G. Oyen, \\ Frans H.M. Corstens, Otto C. Boerman \\ Department of Nuclear Medicine, Radboud University Nijmegen Medical Centre, P.O. Box 9101, 6500 HB Nijmegen, The Netherlands \\ Received 16 April 2007; accepted 28 April 2007
}

\begin{abstract}
It was previously shown that the ${ }^{99 \mathrm{~m}}$ Tc-labeled hydrazinonicotinamide (HYNIC)-conjugated LTB4 antagonist MB81 visualized infectious foci in rabbits adequately and within a few hours after injection. Here, the bivalent HYNIC-conjugated LTB4 antagonist MB67 (analog of MB81) was fluorinated with ${ }^{18} \mathrm{~F}$ via hydrazone formation and tested in vivo.

Methods: MB67 was $\left[{ }^{18} \mathrm{~F}\right]$-fluorinated via reaction of the $\left[{ }^{18} \mathrm{~F}\right]$-fluorinated intermediate $p-\left[{ }^{18} \mathrm{~F}\right]$-fluorobenzaldehyde $\left(\left[{ }^{18} \mathrm{~F}\right] \mathrm{FB}\right)$ and the HYNIC moiety of MB67 via hydrazone formation. For comparison, MB67 was also labeled with ${ }^{99 \mathrm{~m}} \mathrm{Tc}$. The biodistribution of ${ }^{18} \mathrm{~F}-$ and ${ }^{99 \mathrm{~m}}$ Tc-labeled MB67 was investigated in rabbits with intramuscular infection.

Results: $\left[{ }^{18} \mathrm{~F}\right]-\mathrm{MB} 67$ was obtained at a maximum specific activity of $1200 \mathrm{GBq} / \mathrm{mmol}$ and proved to be stable in phosphate buffered saline (PBS) at $37^{\circ} \mathrm{C}$ for at least $4 \mathrm{~h}$. PET images obtained with $\left[{ }^{18} \mathrm{~F}\right]-\mathrm{MB} 67$ clearly delineated the abscess at 2 and $4 \mathrm{~h}$ pi. Counting of dissected tissues at $4 \mathrm{~h}$ pi revealed an abscess uptake of $0.073 \pm 0.005 \% \mathrm{ID} / \mathrm{g}$, as compared to $0.160 \pm 0.010 \% \mathrm{ID} / \mathrm{g}$ for the ${ }^{99 \mathrm{~m}} \mathrm{Tc}-\mathrm{labeled}$ analog. Abscess-to-muscle ratios were $23 \pm 4$ for $\left[{ }^{18} \mathrm{~F}\right]-\mathrm{MB} 67$ and $35 \pm 9$ for [ $\left.{ }^{99 \mathrm{~m}} \mathrm{Tc}\right]-\mathrm{MB} 67$.

Conclusion: The present study showed the feasibility of a new $\left[{ }^{18} \mathrm{~F}\right]$-labeling methodology and its application in the production of a new PET tracer for imaging of infection, $\left[{ }^{18} \mathrm{~F}\right]-\mathrm{MB} 67$.
\end{abstract}

(C) 2007 Elsevier Inc. All rights reserved.

Keywords: PET imaging; HYNIC-conjugated LTB4 antagonist; Hydrazone formation

\section{Introduction}

In previous studies, we demonstrated that the ${ }^{99 \mathrm{~m}} \mathrm{Tc}-$ labeled hydrazinonicotinamide (HYNIC)-conjugated leukotriene B4 (LTB4) antagonists MB88 (monovalent) and MB81 (bivalent) were potent and promising agents for SPECT imaging of infection and inflammation [1]. The LTB4 receptor is expressed on polymorphonuclear granulocytes and is involved in leukocyte function during the inflammatory response. These agents revealed infectious foci in rabbits adequately as early as $2 \mathrm{~h}$ pi. The rapid pharmacokinetics of these agents prompted us to investigate

* Corresponding author. Tel.: +31 24 3615054; fax: +31 243618942 .

E-mail address: h.rennen@nucmed.umcn.nl (H.J.J.M. Rennen). the potential of $\left[{ }^{18} \mathrm{~F}\right]$-fluorinated LTB4 antagonists for PET imaging of infection and inflammation. ${ }^{18} \mathrm{~F}$ is the most commonly used radionuclide for PET and has a half-life of nearly $2 \mathrm{~h}$. PET is rapidly gaining worldwide acceptance and offers distinct advantages over SPECT with ${ }^{99 \mathrm{~m}} \mathrm{Tc}$ with respect to image resolution and the accuracy to quantify uptake. In the present study, we applied a new $\left[{ }^{18} \mathrm{~F}\right]$-labeling methodology to $\left[{ }^{18} \mathrm{~F}\right]$-fluorinate, the HYNIC-conjugated LTB4 antagonist MB67 (analog of MB81), a nonpeptide compound (Fig. 1). The methodology is based on the reaction of an aldehyde, $p-\left[{ }^{18} \mathrm{~F}\right]$ fluoro-benzaldehyde $\left(\left[{ }^{18} \mathrm{~F}\right]\right.$ FB), with the HYNIC moiety of a reagent via hydrazone formation. Applications of this new technology were shown for $\left[{ }^{18} \mathrm{~F}\right]$-labeling of human serum albumin [2], $\mathrm{c}(\mathrm{RGDyK})$ [3], for octreotide and for substance-P [4]. The technology to label peptides and proteins with ${ }^{99 \mathrm{~m}} \mathrm{Tc}$ via HYNIC as adopted extensively by our group $[1,5-8]$ was transformed 
A

$\left[{ }^{18} \mathrm{~F}\right] \mathrm{FB}$
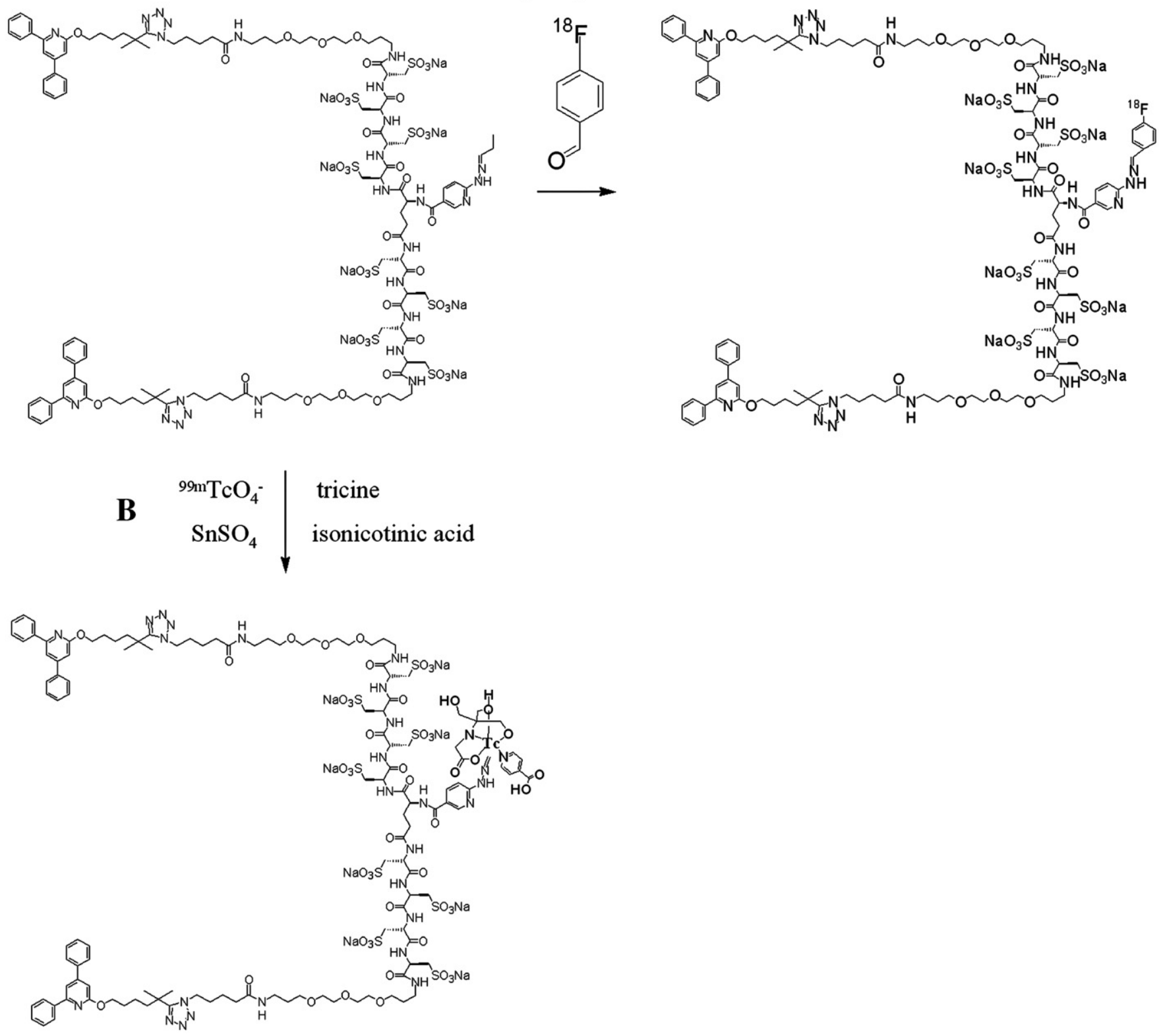

Fig. 1. Chemical structure of HYNIC-LTB4-receptor antagonist MB67 and reaction with $\left[{ }^{18} \mathrm{~F}\right] \mathrm{FB}$ (Reaction A) and ${ }^{99 \mathrm{~m}} \mathrm{TcO}-\mathrm{O}_{4}^{-}$in the presence of coligands tricine and isonicotinic acid (Reaction B).

here to a fluorination technology. Results of $\left[{ }^{18} \mathrm{~F}\right]$-fluorinated MB67 were compared to results obtained with ${ }^{99 \mathrm{~m}} \mathrm{Tc}-$ labeled MB67 in rabbits with soft tissue infection.

\section{Methods}

The HYNIC-conjugated LTB4-receptor antagonist MB67 (Fig. 1) is a derivative of MB81 (BMS5786881 , the synthesis of which has been described in detail elsewhere [9]. MB67 is a bivalent LTB4 antagonist consisting of two identical LTB4 receptor-binding moieties, each modified with tetra-cysteic acid. The LTB4binding moieties are joined using the carboxyl groups of glutamic acid and conjugated with HYNIC. In the case of MB81, the hydrazine moiety of HYNIC was protected by formation of a hydrazone with benzaldehyde; in the case of MB67, the hydrazine moiety was converted into a hydrazone by reaction with propylaldehyde. The propylhydrazone contributes to long-term stability and is 
converted into the kinetically favored hydrazone formed in the reaction with $\left[{ }^{18} \mathrm{~F}\right] \mathrm{FB}$.

\subsection{Radiolabeling}

\subsubsection{Synthesis of $\left[{ }^{18} \mathrm{~F}\right] \mathrm{FB}$}

The synthesis of the unlabeled precursor of $\left[{ }^{18} \mathrm{~F}\right] \mathrm{FB}$, $p$-trimethylammoniumbenzaldehyde triflate, was performed according to Haka et al. [10]. No-carrier-added $\left[{ }^{18} \mathrm{~F}\right]$-fluoride (2-3.5 GBq), on a Sep-Pak ion-exchange QMA cartridge (Waters, Etten-Leur, The Netherlands), was obtained from Cyclotron BV (Amsterdam, The Netherlands). The $\left[{ }^{18} \mathrm{~F}\right]-$ fluoride was eluted from the QMA cartridge into a 5-ml reaction vial (Reacti-Vial, Pierce, Rockford, IL, USA) using $800 \mu \mathrm{l}$ of acetronitrile containing $20 \mathrm{mg}$ of Kryptofix 2.2.2. (Merck, Darmstadt, Germany) and $50 \mu \mathrm{l} 1 \mathrm{M}$ potassium carbonate in water. The solvent was evaporated under a stream of nitrogen at $90^{\circ} \mathrm{C}$. The $\left[{ }^{18} \mathrm{~F}\right]$-fluoride cryptate solution was dried azeotropically three times with $250-\mu 1$ portions of dry acetronitrile.

To the dried $\left[{ }^{18} \mathrm{~F}\right]$-fluoride cryptate, $8 \mathrm{mg}$ of the triflate salt of $p$-trimethylammoniumbenzaldehyde in $500 \mu \mathrm{l}$ of dimethylsulfoxide was added. The vial was closed and heated at $120^{\circ} \mathrm{C}$. After $10 \mathrm{~min}$, the vial was cooled to room temperature and $3 \mathrm{ml}$ of water was added. A cation exchange SCX cartridge (Alltech, Breda, The Netherlands) and a Sep-Pak C18 cartridge (Waters) were preconditioned. The SCX cartridge was used to trap unreacted p-trimethylammoniumbenzaldehyde and the Sep-Pak C18 cartridge was used to immobilize $\left[{ }^{18} \mathrm{~F}\right] \mathrm{FB}$. The reaction mixture was applied onto the cartridges (connected in series), and the cartridges were washed extensively with $15 \mathrm{ml}$ of water. The SCX cartridge was removed and $\left[{ }^{18} \mathrm{~F}\right]$ FB was eluted in $0.15-\mathrm{ml}$ fractions from the Sep-Pak C18 cartridge with $1.5 \mathrm{ml}$ of methanol. Fractions with the highest concentrations of $\left[{ }^{18} \mathrm{~F}\right] \mathrm{FB}$ were pooled and used for subsequent reactions with HYNIC-conjugated LTB4receptor antagonist $\mathrm{MB} 67$ as described in the next paragraph. Aliquots were analyzed on RP-HPLC. An Agilent 1100 series LC system (Agilent Technologies, Palo Alto, CA, USA) equipped with an in-line NaI crystal radiodetector (Raytest, Straubenhardt, Germany) was used for analytical reversed-phase HPLC. An Alltima C18 column $(5 \mu \mathrm{m}, 4.6 \times 250 \mathrm{~mm}$, Alltech) was used at a flow rate of $1 \mathrm{ml} / \mathrm{min}$. Solvent $\mathrm{A}=10 \mathrm{mM}$ ammonium acetate pH 7.2; solvent $\mathrm{B}=100 \%$ acetonitrile. Gradient: $95 \%$ Solvent A, 5\% Solvent B from 0 to $5 \mathrm{~min} ; 5-100 \%$ Solvent B in $15 \mathrm{~min} ; 100 \%$ solvent B for $5 \mathrm{~min}$. In this system, the retention time of $\left[{ }^{18} \mathrm{~F}\right] \mathrm{FB}$ was $18.2 \mathrm{~min}$.

\subsubsection{Labeling of HYNIC-conjugated LTB4 antagonist MB67 with $\left[{ }^{18} \mathrm{~F}\right] \mathrm{FB}$}

For in vivo animal studies, a methanolic aliquot of $120 \mu \mathrm{l}$ $\left[{ }^{18} \mathrm{~F}\right] \mathrm{FB}(600 \mathrm{MBq})$ was reacted with $400 \mu \mathrm{g}(=140 \mathrm{nmol})$ of HYNIC-conjugated LTB4 antagonist MB67 in $120 \mu \mathrm{l}$ of $0.4 \mathrm{M}$ sodium acetate $\mathrm{pH}$ 4.2. The reaction was carried out at $50^{\circ} \mathrm{C}$ for $30 \mathrm{~min}$. The conjugation efficiency was determined by RP-HPLC. To terminate the labeling reaction, an equal volume of $0.5 \mathrm{M}$ phosphate buffer $\mathrm{pH} 7.4$ was added to the reaction mixture. $\left[{ }^{18} \mathrm{~F}\right] \mathrm{FB}$ was separated from $\left[{ }^{18} \mathrm{~F}\right]-\mathrm{MB} 67$ by coevaporation of methanol and $\left[{ }^{18} \mathrm{~F}\right] \mathrm{FB}$ at $50^{\circ} \mathrm{C}$ under a stream of nitrogen. The stability of the purified $\left[{ }^{18} \mathrm{~F}\right]-\mathrm{MB} 67$ preparation in phosphate buffered saline (PBS) was monitored at $37^{\circ} \mathrm{C}$ for $4 \mathrm{~h}$ by HPLC.

${ }^{18}$ F-Fluorinated MB67 was tested in a rabbit model of Escherichia coli-induced focal intramuscular infection [5,8]. Four rabbits were injected with $40 \mathrm{MBq}\left[{ }^{18} \mathrm{~F}\right]-\mathrm{MB} 67$ $(100 \mu \mathrm{g})$ via the lateral ear vein. Prior to imaging, the rabbits were catheterized to void the bladder. Two rabbits were immobilized, placed side by side on the PET scanner (ECAT-EXACT, Siemens/CTI, Knoxville, TN, USA), and images were recorded in $3 \mathrm{D}$ mode at 2 and $4 \mathrm{~h}$ pi. For comparison, three rabbits with an $E$. coli-induced intramuscular infection received $5 \mathrm{MBq}$ of ${ }^{99 \mathrm{~m}}$ Tc-labeled MB67. MB67 was labeled with ${ }^{99 m}$ Tc by adding $300 \mathrm{MBq}$ Na- ${ }^{99 m} \mathrm{TcO}_{4}$ (Tyco Healthcare Mallinkrodt, Petten, The Netherlands) to $10 \mu \mathrm{g}$ of MB67 in the presence of $15 \mathrm{mg}$ tricine, $2 \mathrm{mg}$ isonicotinic acid in $350 \mu \mathrm{PBS}, \mathrm{pH} 7.0$ and $25 \mu \mathrm{l} \mathrm{SnSO}_{4}(1 \mathrm{mg} / \mathrm{ml})$ in $0.1 \mathrm{~N} \mathrm{HCl}$. After incubation for $30 \mathrm{~min}$ at $100^{\circ} \mathrm{C}$, quality control was performed using RPHPLC as described above.

After completion of the final PET image ( $4 \mathrm{~h}$ pi), all rabbits were euthanized with a lethal dose of pentobarbital (Euthesate, Ceva Sante Animale, Naaldwijk, The Netherlands) and the biodistribution of the ${ }^{18} \mathrm{~F}$ and ${ }^{99 \mathrm{~m}} \mathrm{Tc}$ radiolabels was determined as described previously [5,8]. The animal experiment was reviewed and approved by the local animal welfare committee and performed in accordance with Dutch governmental guidelines.

\section{Results}

\subsection{Synthesis of $\left[^{18} \mathrm{~F}\right] \mathrm{FB}$}

Direct $\left[{ }^{18} \mathrm{~F}\right]$-fluorination of $p$-trimethylammoniumbenzaldehyde triflate using dried $\left[{ }^{18} \mathrm{~F}\right]$-fluoride cryptate was complete within $10 \mathrm{~min}$ at $120^{\circ} \mathrm{C}$. Purification of $\left[{ }^{18} \mathrm{~F}\right] \mathrm{FB}$ on a combination of a cation-exchange cartridge ( $\mathrm{SCX}$ ) and a reversed phase cartridge $(\mathrm{C} 18)$ resulted in a product with a radiochemical purity that always exceeded 95\%. By elution of immobilized $\left[{ }^{18} \mathrm{~F}\right] \mathrm{FB}$ from the $\mathrm{C} 18$ cartridge in reversed direction and by fractionated collection of methanolic $\left[{ }^{18} \mathrm{~F}\right]$ FB from this cartridge, a high activity concentration was obtained (2-4 MBq/ $\mu \mathrm{l})$. The overall synthesis time, including purification, was $30 \mathrm{~min}$ with an overall decay corrected radiochemical yield of between $65 \%$ and $85 \%$.

\subsection{Synthesis of $\left[^{18} \mathrm{~F}\right]-M B 67$ and PET imaging}

$\left[{ }^{18} \mathrm{~F}\right]-\mathrm{MB} 67$ was obtained from the reaction of MB67 with $\left[{ }^{18} \mathrm{~F}\right] \mathrm{FB}$ at a maximum specific activity of $1200 \mathrm{GBq} /$ mmol. $\left[{ }^{18} \mathrm{~F}\right] \mathrm{FB}$ conjugated to MB67 proved to be stable: the release of $\left[{ }^{18} \mathrm{~F}\right] \mathrm{FB}$ amounted to only $2 \%$ after $4 \mathrm{~h}$ of incubation in $\mathrm{PBS}$ at $37^{\circ} \mathrm{C}$. 


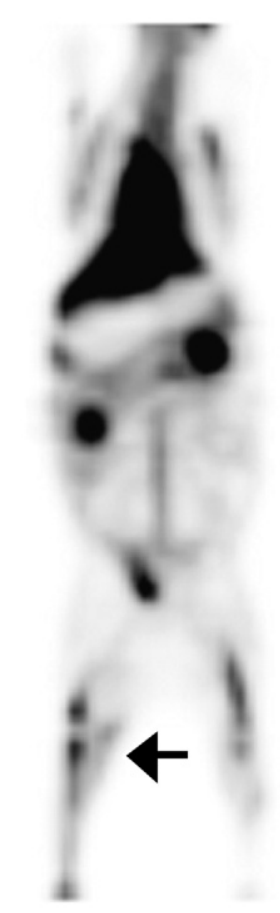

$2 \mathrm{~h}$

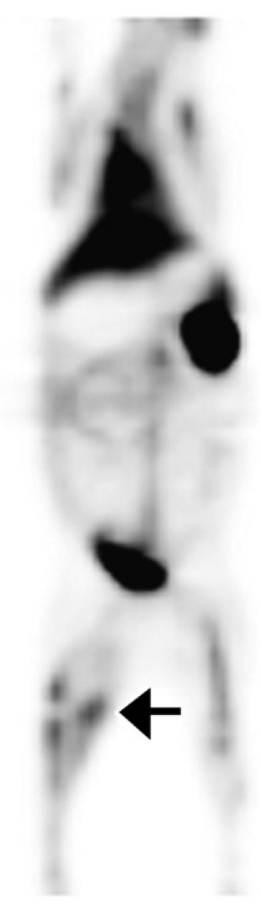

$4 \mathrm{~h}$
Fig. 2. Coronal posterior slices of PET images of a rabbit with an E. coli abscess in the left thigh muscle at 2 and $4 \mathrm{~h}$ after injection of $40 \mathrm{MBq}$ of the $\left[{ }^{18} \mathrm{~F}\right]$-labeled leukotriene B4 receptor antagonist MB67. Arrows indicate the site of infection.

PET images of a rabbit with focal infection acquired at 2 and $4 \mathrm{~h}$ after injection of $\left[{ }^{18} \mathrm{~F}\right]-\mathrm{MB} 67$ are presented in Fig. 2. The abscess was delineated already at $2 \mathrm{~h} \mathrm{pi}$, and the image quality improved with time. The biodistribution of $\left[{ }^{18} \mathrm{~F}\right]-$ MB67 and $\left[{ }^{99 m} \mathrm{Tc}\right]-M B 67$ in rabbits as determined in dissected tissues is shown in Fig. 3. For $\left[{ }^{18} \mathrm{~F}\right]-\mathrm{MB} 67$, significantly lower values $(P<.05)$ for radioactivity uptake in the abscess, spleen and liver were observed as compared to its ${ }^{99 \mathrm{~m}} \mathrm{Tc}$-labeled counterpart, whereas radioactivity uptake in the other organs showed no significant differences. The obtained abscess-to-blood and abscess-to-muscle ratios were not significantly different either.

\section{Discussion}

In the present study, an application of a new $\left[{ }^{18} \mathrm{~F}\right]-$ labeling methodology for $\left[{ }^{18} \mathrm{~F}\right]$-fluorination of hydrazinefunctionalized compounds is described. This fluorination methodology is based on the reaction of an aldehyde, $\left[{ }^{18} \mathrm{~F}\right]$ FB, with a hydrazinonicotinic acid (HYNIC) functionalized compound, forming a hydrazone bond. Chang et al. [2] presented the first report on fluorination of a protein, human serum albumin, using this methodology. The same methodology was successfully used to fluorinate small peptides such as c(RGDyK) [3], octreotide or substance-P [4] as well.
This is the first report on $\left[{ }^{18} \mathrm{~F}\right]$-fluorination of a nonpeptide/ protein compound, the LTB4 antagonist MB67, via hydrazone formation, and the first PET images are presented here.

$\left[{ }^{18} \mathrm{~F}\right]-\mathrm{MB} 67$ was obtained at a maximum specific activity of $1200 \mathrm{GBq} / \mathrm{mmol}$ and was stable in $\mathrm{PBS}$ at $37^{\circ} \mathrm{C}$ for at least 4 h. PET imaging with $\left[{ }^{18} \mathrm{~F}\right]-\mathrm{MB} 67$ showed a clear delineation of the infectious foci in rabbits and confirmed the feasibility of the new $\left[{ }^{18} \mathrm{~F}\right]$-fluorination approach for in vivo targeting. The in vivo biodistribution of $\left[{ }^{18} \mathrm{~F}\right]-\mathrm{MB} 67$ showed some similarity to that of $\left[{ }^{99 \mathrm{~m}} \mathrm{Tc}\right]-\mathrm{MB} 67$, although some differences were observed. Lower uptake of $\left[{ }^{18} \mathrm{~F}\right]-$ MB67 in abscess and spleen is most likely due to slight differences in the physicochemical characteristics of $\left[{ }^{18} \mathrm{~F}\right]-$ MB67 as compared to $\left[{ }^{99 \mathrm{~m}} \mathrm{Tc}\right]-\mathrm{MB} 67$. These differences may reduce the ability of $\left[{ }^{18} \mathrm{~F}\right]-\mathrm{MB} 67$ to bind its receptors on neutrophils. In $\left[{ }^{18} \mathrm{~F}\right]-\mathrm{MB} 67$, the fluorinated prosthetic group is uncharged, whereas in its ${ }^{99 \mathrm{~m}} \mathrm{Tc}$-labeled counterpart the ${ }^{99 \mathrm{~m}} \mathrm{Tc}$-core with surrounding coligands is charged (Fig. 1). The introduction of an additional benzyl group by binding of $\left[{ }^{18} \mathrm{~F}\right] \mathrm{FB}$ to the HYNIC moiety of a compound results in a more lipophilic product and this may have affected the biological properties of the $\left[{ }^{18} \mathrm{~F}\right]$-fluorinated compound negatively. In the case of $\left[{ }^{18} \mathrm{~F}\right]-\mathrm{MB} 67$, the lipophilicity was counteracted by its eight hydrophilic cysteic acid

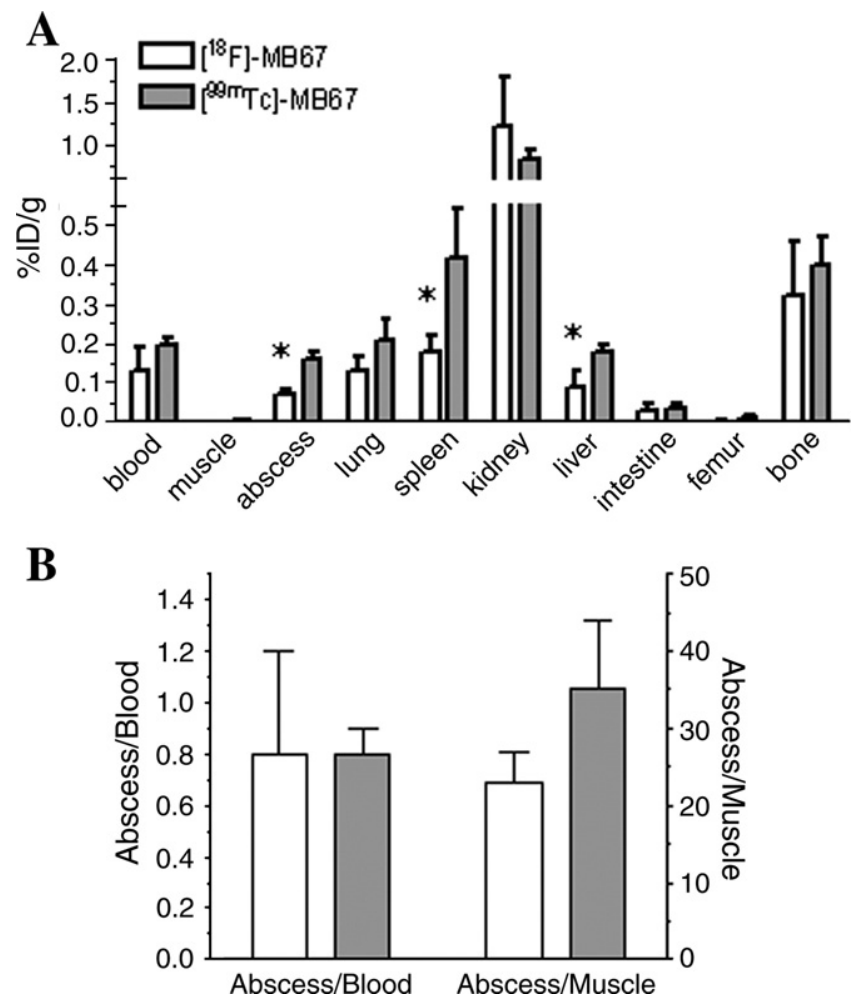

Fig. 3. Biodistribution at $4 \mathrm{~h}$ pi of the ${ }^{18} \mathrm{~F}$-labeled leukotriene $\mathrm{B} 4$ receptor antagonist MB67 and its ${ }^{99 \mathrm{~m}}$ Tc-labeled analog in rabbits with E. coli infections (mean \pm 1 S.E.M.). $P<.05$ (unpaired two-tailed $t$ test). Comparison of uptake of the two radiolabels in various organs, expressed as percentage of the injected dose per gram of tissue $(\% \mathrm{ID} / \mathrm{g}, \mathrm{A})$ and a comparison of abscess-to-blood and abscess-to-muscle ratios (B). 
residues, but in the case of another relatively small compound such as $\left[{ }^{18} \mathrm{~F}\right] \mathrm{FB}$-octreotide, the increase in lipophilicity was highly significant: the log value of the octanol-water partition coefficient $\left(\log P_{\mathrm{o} / \mathrm{w}}\right)$ of $\left[{ }^{125} \mathrm{I}\right]$ iodinated octreotide was minus $0.77 \pm 0.04$ as compared to $1.49 \pm 0.09$ for $\left[{ }^{18} \mathrm{~F}\right] \mathrm{FB}-$ octreotide [4]. Also, the reported decrease in affinity of $\left[{ }^{18} \mathrm{~F}\right] \mathrm{FB}-\mathrm{HYNIC}-\mathrm{c}(\mathrm{RGDyK})$ as compared to $\mathrm{c}(\mathrm{RGDyK})$ for $\alpha_{\mathrm{v}} \beta_{3}$-integrin might be explained by the presence of two additional lipophilic aromatic systems in the HYNIC and $\left[{ }^{18} \mathrm{~F}\right] \mathrm{FB}$ moieties of $\left[{ }^{18} \mathrm{~F}\right] \mathrm{FB}-\mathrm{HYNIC}-\mathrm{c}(\mathrm{RGDyK})$ [3].

The specific activity of the $\left[{ }^{18} \mathrm{~F}\right]-\mathrm{MB} 67$ preparation used was much lower than that of the ${ }^{99 \mathrm{~m}}$ Tc-labeled product: $100 \mu \mathrm{g}$ of $\left[{ }^{18} \mathrm{~F}\right]-\mathrm{MB} 67$ was injected per rabbit as opposed to only $3 \mu \mathrm{g}$ of [ $\left.{ }^{99 \mathrm{~m}} \mathrm{Tc}\right]-\mathrm{MB} 67$. Hydrazone formation is favored by high concentrations of the hydrazine-containing compound. However, $\left[{ }^{18} \mathrm{~F}\right] \mathrm{FB}$ is a highly volatile compound and cannot be easily concentrated before reaction with MB67. A relatively high amount of MB67 had to be added in order to obtain a reasonable labeling efficiency. As a consequence of a modest specific activity of $\left[{ }^{18} \mathrm{~F}\right]-\mathrm{MB} 67$, receptor saturation due to the higher dose of unlabeled MB67 could have occurred. Although specific abscess uptake was demonstrated with the fluorinated compound, the relatively low specific activity may limit the application of this $\left[{ }^{18} \mathrm{~F}\right]-$ labeling approach. The relatively low specific activity of a $\left[{ }^{18} \mathrm{~F}\right]$-labeled tracer could result in reduced uptake in the target tissue due to receptor saturation. Furthermore, the relatively high dose of the radiotracer could induce pharmacological effects. In our case, pharmacologic effects were not observed after administration of $100 \mu \mathrm{g}\left[{ }^{18} \mathrm{~F}\right]-$ MB67 per rabbit, which is in line with our previous observation that administration of a dose as high as $2 \mathrm{mg}$ of LTB4 antagonist in rabbits does not result in significant changes in white blood cell counts [11].

Furthermore, this approach can only be applied to receptor binding ligands of which the pharmacokinetics match the physical half-life of ${ }^{18} \mathrm{~F}$ (108 $\left.\mathrm{min}\right)$. In the case of $\left[{ }^{18} \mathrm{~F}\right]-\mathrm{MB} 67$, PET imaging of infection was feasible at $2 \mathrm{~h}$ pi, but imaging at $4 \mathrm{~h}$ pi resulted in higher uptake in the abscess and higher abscess-background ratios. The kinetics of MB67 match better with ${ }^{99 m}$ Tc (physical half-life of $6 \mathrm{~h}$ ) than with ${ }^{18} \mathrm{~F}$.

The use of $\left[{ }^{18} \mathrm{~F}\right]-\mathrm{MB} 67$ may offer distinct advantages over that of its ${ }^{99 \mathrm{~m}} \mathrm{Tc}$-labeled counterpart, in particular applications where the enhanced resolution of PET (and PET-CT) imaging could be exploited, e.g., in colitis, appendicitis and endocarditis (especially in combination with CT).

\section{Conclusion}

In the present study, we demonstrated the feasibility of the $\left[{ }^{18} \mathrm{~F}\right]$ hydrazone formation strategy for PET imaging of infection using an LTB4 antagonist. This study confirms the use of HYNIC-functionalized precursors for $\left[{ }^{18} \mathrm{~F}\right]$-labeling besides its use for ${ }^{99 \mathrm{~m}}$ Tc-labeling. At this point the approach has a few limitations: (1) the specific activity of the tracer is relatively low; (2) fluorination with this method enhances the lipophilicity of the tracer; (3) application of this approach is restrained to tracers with fast pharmacokinetics. Despite its limitations, this approach offers a new way to label (non) peptides with ${ }^{18} \mathrm{~F}$ for various applications in PET. Further research is warranted to optimize this versatile fluorination strategy to obtain a tracer with a higher specific activity to broaden the application of this method.

\section{Acknowledgments}

The authors thank Matthias Broekema (Department of Medicinal Chemistry, Utrecht University, Utrecht, The Netherlands) for synthesis of the LTB4 antagonists.

\section{References}

[1] van Eerd JE, Broekema M, Harris TD, Edwards DS, Oyen WJ, Corstens $\mathrm{FH}$, et al. Imaging of infection and inflammation with an improved ${ }^{99 \mathrm{~m}}$ Tc-labeled LTB4 antagonist. J Nucl Med 2005;46: $1546-51$.

[2] Chang YS, Jeong JM, Lee YS, Kim HW, Rai GB, Lee SJ, et al. Preparation of ${ }^{18} \mathrm{~F}$-human serum albumin: a simple and efficient protein labeling method with ${ }^{18} \mathrm{~F}$ using a hydrazone-formation method. Bioconjug Chem 2005;16:1329-33.

[3] Lee YS, Jeong JM, Kim HW, Chang YS, Kim YJ, Hong MK, et al. An improved method of ${ }^{18} \mathrm{~F}$ peptide labeling: hydrazone formation with HYNIC-conjugated c(RGDyK). Nucl Med Biol 2006;33:677-83.

[4] Bruus-Jensen K, Poethko T, Schottelius M, Hauser A, Schwaiger M, Wester HJ. Chemoselective hydrazone formation between HYNICfunctionalized peptides and ${ }^{18} \mathrm{~F}$-fluorinated aldehydes. Nucl Med Biol 2006;33:173-83.

[5] Rennen HJ, Boerman OC, Oyen WJ, van der Meer JW, Corstens FH. Specific and rapid scintigraphic detection of infection with ${ }^{99 \mathrm{~m}} \mathrm{Tc}$ labeled interleukin-8. J Nucl Med 2001;42:117-23.

[6] Rennen HJ, Boerman OC, Oyen WJ, Corstens FH. Kinetics of ${ }^{99 \mathrm{~m}}$ Tc-labeled interleukin- 8 in experimental inflammation and infection. J Nucl Med 2003;44:1502-9.

[7] Rennen HJ, Boerman OC, Koenders EB, Oyen WJ, Corstens FH. Labeling proteins with Tc-99m via hydrazinonicotinamide (HYNIC): optimization of the conjugation reaction. Nucl Med Biol 2000;27: 599-604.

[8] Rennen HJ, van Eerd JE, Oyen WJ, Corstens FH, Edwards DS, Boerman OC. Effects of coligand variation on the in vivo characteristics of Tc- $99 \mathrm{~m}$-labeled interleukin- 8 in detection of infection. Bioconjug Chem 2002;13:370-7.

[9] Broekema M, van Eerd JJ, Oyen WJ, Corstens FH, Liskamp RM, Boerman OC, et al. Synthesis of leukotriene B4 antagonists labeled with In-111 or Tc-99m to image infectious and inflammatory foci. J Med Chem 2005;48:6442-53.

[10] Haka MS, Kilbourn MR, Watkins GL, Toorongian SA. Aryltrimethylammonium trifluoromethanesulfonates as precursors to aryl ${ }^{18}$ F-fluorides: improved synthesis of ${ }^{18} \mathrm{~F}-\mathrm{GBR}-13119$. J Labelled Compds Radiopharm 1989;27:823-33.

[11] van Eerd JE, Oyen WJ, Harris TD, Rennen HJ, Edwards DS, Liu S, et al. A bivalent leukotriene B4 antagonist for scintigraphic imaging of infectious foci. J Nucl Med 2003;44:1087-91. 